\title{
Comparison between the Nereis diversicolor and Nereis virens marine worms in the transformation of ingested hydrocarbons
}

\author{
F. Gilbert*ో, G. Desrosiers ${ }^{\dagger}$, S. Hulth ${ }^{\ddagger}$ and G. Stora* \\ *Laboratoire d'Océanographie et de Biogéochimie (UMR CNRS 6535), Campus de Luminy, case 901, \\ F-13288 Marseille Cedex 9, France. ${ }^{\dagger}$ Institut des Sciences de la Mer (ISMER), Université du Québec à \\ Rimouski, 310 allée des Ursulines, Rimouski, Québec, G5L 3A1, Canada. ${ }^{\ddagger}$ Department of Analytical and \\ Marine Chemistry, Göteborg University, S-41296 Göteborg, Sweden. E-mail: gilbert@com.univ-mrs.fr
}

\begin{abstract}
A feeding experiment was conducted on the marine worm Nereis diversicolor to compare the fate of a hydrocarbon mixture during the gut passage in this species with the hydrocarbon breakdown process demonstrated for Nereis virens. Hydrocarbon dissolution/solubilization processes in the gut of $\mathcal{N}$. diversicolor were found to have similar qualitative and quantitative importance in the hydrocarbon transformation as those observed in $\mathcal{N}$. virens.
\end{abstract}

\begin{abstract}
Macrobenthic worm species are known to play an important role in the vertical redistribution of hydrocarbons in the sedimentary column and subsequent degradation by microbes (Lee \& Swartz, 1980; McElroy et al., 1990). In areas of intensive reworking, ingestion of hydrocarbons adsorbed to sediment particles may induce direct hydrocarbon transformation during the transit. Mayer et al. (1996) discovered a potentially powerful dissolving process for organic matter related to the production of surfactants inside the gut of the deposit-feeders. Most recently, this process was demonstrated and quantified for Nereis virens (Sars) species (Bock \& Mayer, 1999; Gilbert et al., 2001). The aim of our present work was to investigate if Nereis diversicolor (O.F. Müller) has a similar capacity to transform ingested hydrocarbons as Nereis virens and thus plays an important role in the transport and transformation of hydrocarbons in bioturbated surface deposits.
\end{abstract}

Eighteen adult $\mathcal{N}$. diversicolor were collected in the Carteau Cove (Gulf of Fos, Mediterranean Sea, France) in February 2000. A similar experimental design was employed as that previously used for $\mathcal{N}$. virens (Gilbert et al., 2001) adapted to $\mathcal{N}$. diversicolor (animal size, period of faeces evacuation). After a 7-d starvation period, each worm was introduced in a horizontal glass tube. Tubes were placed in experimental containers (three worms per container) filled with filtered and aerated seawater under constant temperature $\left(15^{\circ} \mathrm{G}\right)$ and L:D cycle $(12 \mathrm{~h}: 12 \mathrm{~h})$. Once a day, the polychaetes were individually fed with a portion of fresh algae Enteromorpha spp. (9.4 $\pm 1.1 \mathrm{mg}$; mean $\pm \mathrm{SD} ; \mathrm{N}=216$ ) anaesthetized with a mixture of alkanes $\left(n-\mathrm{C}_{14}, n-\mathrm{C}_{15}, n-\mathrm{C}_{17}, n-\mathrm{C}_{18}\right.$, $n-\mathrm{C}_{22}, n-\mathrm{C}_{23}, \quad n-\mathrm{C}_{28}$ and $n-\mathrm{C}_{29}$, pristane and androstane: $2.4 \pm 0.3 \mathrm{mg}$; mean $\pm \mathrm{SD} ; \mathrm{N}=216)$. After four, eight, 12 and $24 \mathrm{~h}$, the faeces were sampled in each container, weighed, and frozen. The sum of faeces collected during the $24 \mathrm{~h}$ period after worm feeding was used for the analysis of the aliphatic hydrocarbons. Eventual food residues were removed, and the sea water replaced prior to feeding. The worms were fed over a period of $12 \mathrm{~d}$. After ten, 11 and $12 \mathrm{~d}$, the worms in one container were sacrificed, and their gut tissues isolated, weighed and frozen before analysis of aliphatic hydrocarbon content. In an additional container without worms, three food rations were separately subjected to the same experimental conditions for $24 \mathrm{~h}$ and served as controls. The aliphatic hydrocarbons were extracted from the homogenized algae, worm faeces and gut tissues and analysed by GG/ MS (Gilbert et al., 2001). Differences between species were studied using a one-way ANOVA after transformation of the heteroscedastic data.

Hydrocarbon content in the faeces of $\mathcal{N}$. diversicolor were found to be more or less constant throughout the duration of the experiment (Table 1). A similar observation was made in $\mathcal{N}$. virens (Gilbert et al., 2001). In order to give a readable presentation of the data, three randomly chosen sets of data were used as triplicates (corresponding to days eight, nine and 11) to compare results between the two species.

The quantitative distributions of hydrocarbon tracer in gut tissues and faeces were different for the two species (Table 1, Figure 1). After ingestion of the algal material, the gut tissue content were not significantly different between the two species $(P=0.24$, Table 1). However, the percentage of tracer in faeces with regard to the initial food portion content was significantly higher $(P>0.05)$ for $\mathcal{N}$. diversicolor than for $\mathcal{N}$. virens. Only 36.8 and $51.1 \%$ of the ingested hydrocarbon tracer was found associated with worm gut tissues and solid material (faeces), for $\mathcal{N}$. virens and $\mathcal{N}$. diversicolor, respectively, suggesting greater rejection of the tracer by $\mathcal{N}$. virens as non-solid material.

All the compounds of the initial tracer mixture were present in the control, $\mathcal{N}$. diversicolor and $\mathcal{N}$. virens faeces (Figure 1). In both the control and the faeces there was a reduction of the alkane content, which was most pronounced for the low molecular weight $n$-alkane (LALK; from $n-\mathrm{C}_{14}$ to $n-\mathrm{C}_{18}$ ) than the heavy molecular weight $\underline{n}$-alkanes (HALK; from $n-\mathrm{C}_{22}$ to $n-\mathrm{C}_{29}$ ). An increased loss of the low molecular weight compounds was apparent in the faeces, whereas the differences measured for the highest molecular weight $n$-alkanes had decreased. This resulted in a global decrease of the LALK/HALK ratios in the faeces compared to the control (Figure 1). Moreover, this tendency 
Table 1. Percentage of the hydrocarbon mixture recovered in gut tissues and faeces of Nereis virens and Nereis diversicolor compared to the initial hydrocarbon food portion content. Values are mean $\pm S D(\mathcal{N}=3)$.

\begin{tabular}{lcc}
\hline & Gut tissues & Faeces \\
\hline Nereis virens & $3.1 \pm 2.6$ & $33.7 \pm 5.5$ \\
Nereis diversicolor & $1.2 \pm 0.7$ & $48.9 \pm 3.3$ \\
\hline
\end{tabular}

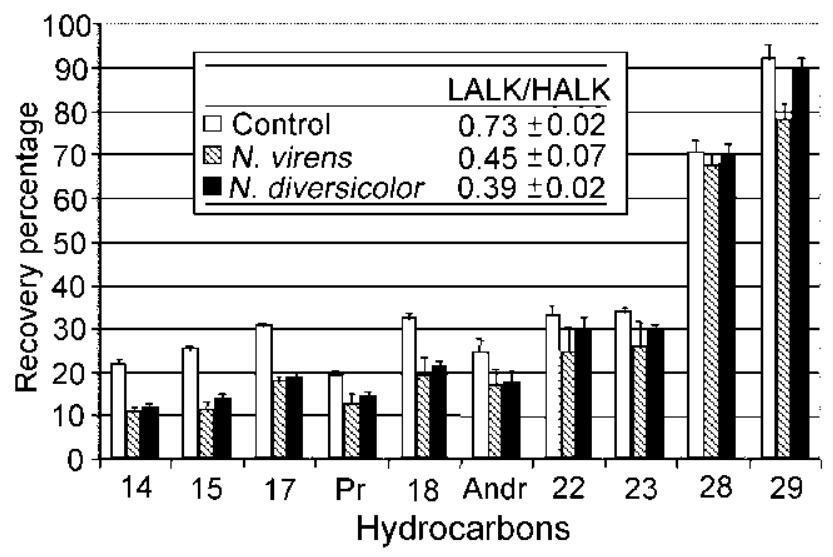

Figure 1. Percentage (mean $\pm \mathrm{SD} ; \mathrm{N}=3$ ) of the various hydrocarbon compounds recovered in the control and the faeces of Nereis virens and Nereis diversicolor (sum of faeces collected during the $24 \mathrm{~h}$ period after worm feeding) compared to the initial tracer (food portion) composition. Numbers refer to carbons in $n$-alkanes $\left(n-\mathrm{C}_{14}\right.$ to $\left.n-\mathrm{C}_{29}\right)$; Pr, pristane; Andr, androstane; LALK/HALK, ratio between the low molecular weight $n$-alkanes (LALK; from $n$ - $\mathrm{C}_{14}$ to $n$ - $\mathrm{C}_{18}$ ) and the heavy molecular weight $n$-alkanes (HALK; from $n-\mathrm{C}_{22}$ to $n$ - $\mathrm{C}_{29}$ ) ratio.

$(P=0.26)$ seems to be more important for $\mathcal{N}$. virens than for $\mathcal{N}$. diversicolor.

As previously demonstrated in $\mathcal{N}$. virens (Gilbert et al., 2001), the ingestion and excretion of the hydrocarbon mixture by $\mathcal{N}$. diversicolor stimulated the loss of hydrocarbons compared to the controls. This may suggest that similar processes, such as increased organic matter dissolution/solubilization due to surfactant production inside the gut (Mayer et al., 1997; Bock \& Mayer, 1999), are also important for $\mathcal{N}$. diversicolor. However, it seems that subsequent loss of hydrocarbons in the liquid phase $(49.1 \%)$ was lower for $\mathcal{N}$. diversicolor than for $\mathcal{N}$. virens $(63.7 \%)$ suggesting, in addition with the hydrocarbon gut and faeces content measured, a reduced alkane absorption efficiency by $\mathcal{N}$. diversicolor (Ahrens et al., 2001). The lower digestive potential for $\mathcal{N}$. diversicolor could be attributed to: (i) the difference in body size between worms in the two studies $(3.160 .29 \mathrm{~g}$, mean \pm SD, $\mathrm{N}=20$, Gilbert et al., 2001, and $0.570 .05 \mathrm{~g}, \mathrm{~N}=18$ for $\mathcal{N}$. virens and $\mathcal{N}$. diversicolor) as demonstrated within a Nereis succinea population (Ahrens et al., in press); and (ii) the thermal experimental conditions used in the studies. Indeed, a temperature of $15^{\circ} \mathrm{C}$ may have enhanced general activities for the $\mathcal{N}$. virens species sampled in the Saint-Lawrence estuary, Canada (Desrosiers et al., 1994). It may on the other hand have induced lower activities for the Mediterranean $\mathcal{N}$. diversicolor species that are normally used to more elevated temperatures.

Although some eventual artefacts associated with the experimental set-up, the primary conclusion of our study is that $\mathcal{N}$. diversicolor species induced similar changes to an ingested hydrocarbon mixture than were previously demonstrated for $\mathcal{N}$. virens. These two worms may thus significantly influence the fate and distribution patterns of hydrocarbons in surface sediments.

We thank an anonymous referee and M.J. Ahrens who helped to improve our manuscript. This work was supported by the GDR 1123 'HYCAR' (France) and the Preem Environment Foundation (Sweden).

\section{REFERENCES}

Ahrens, M.J., Hertz, J., Lamoureux, E., Lopez, G.R., McElroy, A.E. \& Brownawell, B.J. The effect of body size on digestive chemistry and absorption efficiencies of food and sedimentbound organic contaminants in Nereis succinea Polychaeta. Journal of Experimental Marine Biology and Ecology, in press.

Ahrens, M.J., Hertz, J., Lamoureux, E., Lopez, G.R., McElroy, A.E. \& Brownawell, B.J., 2001. The role of digestive surfactants in determining bioavailability of sediment-bound hydrophobic organic contaminants to two deposit-feeding polychaetes. Marine Ecology Progress Series, 212, 145-157

Bock, M.J. \& Mayer, L.M., 1999. Digestive plasticity of the marine benthic omnivore Nereis virens. Fournal of Experimental Marine Biology and Ecology, 240, 77-92.

Desrosiers, G., Caron, A., Olivier, M. \& Miron, G., 1994. Cycle de développement d'une population intertidale de Nereis virens (Polychaeta Nereidae) de l'estuaire maritime du Saint Laurent. Oceanologica Acta, 17, 683-695.

Gilbert, F., Stora, G., Desrosiers, G., Deflandre, B., Bertrand, J-C., Poggiale, J-C. \& Gagné, J-P., 2001. Alteration and release of aliphatic compounds by the polychaete Nereis virens (Sars) experimentally fed with hydrocarbons. Fournal of Experimental Marine Biology and Ecology, 256, 199-213.

Lee, H. \& Swartz, R.G., 1980. Biological processes affecting the distribution of pollutants in marine sediments. Part II. Biodeposition and bioturbation. In Contaminants and sediments (ed. R.A. Baker), pp. 555-606. Ann Arbor: Ann Arbor Science Publishing.

Mayer, L.M., et al. 1996. Bioavailability of sedimentary contaminants subject to deposit-feeder digestion. Environmental Science and Technology, 30, 2641-2645.

Mayer, L.M., Schick, L.L., Self, R.F.L., Jumars, P.A., Findlay, R.H., Chen, Z. \& Sampson, S., 1997. Digestive environments of benthic macroinvertebrate guts: enzymes, surfactants and dissolved organic matter. Fournal of Marine Research, 55, 785-812.

McElroy, A.E., Farrington, J.W. \& Teal, J.M., 1990. Influence of mode of exposure and the presence of a tubiculous polychaete on the fate of Benz(a)anthracene in the benthos. Environmental Science and Technology, 24, 1648-1655. 